\title{
Magnesium as an Effective Adjunct Therapy for Drug Resistant Seizures
}

\author{
Peter A. Abdelmalik, Nina Politzer, Peter L. Carlen
}

\begin{abstract}
Objective: To explore the use of magnesium $(\mathrm{Mg})$, an endogenous ion and enzymatic co-factor used in a variety of medical applications, for the treatment of epileptic seizures resistant to traditional medical therapy. Background: For almost a century, $\mathrm{Mg}$ has been used as prophylaxis and treatment of seizures associated with eclampsia. $\mathrm{Mg}$ is a CNS depressant, with numerous functions intracellularly and extracellularly. However, because of the availability of well studied anticonvulsant drugs, Mg has not been tested widely in the treatment of epileptic seizures. Methods: A retrospective chart review of 22 cases of drug resistant epilepsy, where a trial of empiric oral $\mathrm{Mg}$ supplementation (mainly in the form of Mg-oxide) was conducted. Results: Oral Mg supplementation was associated with a significant decrease in the number of seizure days per month, from $15.3 \pm 13.2$ (mean \pm SD) to $10.2 \pm 12.6$ at first follow up ( 3 6 months, $\mathrm{p}=0.021)$, and to $7.8 \pm 10.0$ seizure days/month at second follow up (6-12 months, $\mathrm{p}=0.004)$. Thirty-six percent had a response rate of $75 \%$ or greater at second follow-up. Two patients reported seizure freedom. Most patients were well maintained on $\mathrm{MgO} 420 \mathrm{mg}$ twice a day, or in 2 cases, Mg Lactate, without significant adverse effects, the most frequent being diarrhea (4/22). Discussion: These results suggest that oral $\mathrm{Mg}$ supplementation may prove to be a worthwhile adjunctive medication in treating drug intractable epilepsy. Conclusions: A prospective, double-blinded, placebo controlled study is warranted to evaluate the potential of Mg for the treatment of drug-resistant seizures.
\end{abstract}

RÉSUMÉ: Le magnésium comme traitement d'appoint efficace dans les crises convulsives résistantes au traitement. Objectif : Le but de l'étude était d'explorer l'utilisation du magnésium $(\mathrm{Mg})$, un ion endogène et un cofacteur enzymatique ayant différentes applications en médecine, dans le traitement des crises épileptiques résistantes au traitement médical traditionnel. Contexte : Depuis près d'un siècle, le Mg a été utilisé en prophylaxie et dans le traitement des convulsions associées à l'éclampsie. L'effet du Mg sur le SNC est un effet dépresseur et il a également plusieurs fonctions à l'intérieur et à l'extérieur de la cellule. Cependant, le $\mathrm{Mg}$ a été peu évalué comme anticonvulsivant à cause de la disponibilité de médicaments dont l'efficacité est déjà bien établie. Méthode : Nous avons révisé rétrospectivement les dossiers de 22 patients atteints d'épilepsie réfractaire au traitement médicamenteux qui ont été traités de façon empirique par un supplément oral de Mg (surtout sous forme d'oxyde de Mg). Résultats : La prise d'un supplément de $\mathrm{Mg}$ par voie orale était associée à une diminution significative du nombre mensuel des crises, soit de 15,3 $\pm 13,2$ (moyenne \pm ET) à 10,2 $\pm 12,6$ à la première visite de suivi après 3 à 6 mois de traitement $(\mathrm{p}=0,021)$ et à $7,8 \pm 10,0$ crises par mois au moment de la deuxième visite de suivi après 6 à 12 mois de traitement $(\mathrm{p}=0,004)$. Trente-six pour cent des patients avaient un taux de réponse de $75 \%$ ou plus au moment de la deuxième visite de suivi. Deux patients ont rapporté qu'ils n'avaient plus de crises. La plupart des patients étaient stables sous $\mathrm{MgO} 420 \mathrm{mg}$ deux fois par jour ou, chez deux patients, sous lactate de Mg, sans effets indésirables importants le plus fréquent étant la diarrhée (4/22). Discussion : Selon ces résultats, la supplémentation orale en $\mathrm{Mg}$ peut s'avérer utile comme médicament d'appoint dans le traitement de l'épilepsie réfractaire au traitement médical. Conclusion : Il serait pertinent d'évaluer par une étude prospective, à double insu, contrôlée par placebo, le potentiel du Mg dans le traitement des crises résistantes au traitement médicamenteux.

Can J Neurol Sci. 2012; 39: 323-327

The definitive treatment of eclampsia, a syndrome of pregnancy-induced hypertension, proteinuria and new onset seizures, is magnesium ( $\mathrm{Mg}$ ) supplementation, followed by delivery of the fetus. Magnesium has been the widely accepted treatment since first reported in $1925^{1}$, and remains the mainstay of treatment for eclampsia. Eclamptic seizures have been compared, both in semiology and electrographically, to generalized tonic-clonic (GTC) "grand mal" seizures, with controlled clinical trials having demonstrated the clear effectiveness of $\mathrm{Mg}$ against eclamptic seizures when compared to conventional anticonvulsants ${ }^{2,3}$.

Magnesium has been hypothesized to be effective against CNS ischemia and seizures based on its biochemical properties ${ }^{4}$. Magnesium is a known CNS depressant, whose mechanisms of action include: competitive antagonism of N-methyl-D-aspartate (NMDA) receptors, blocking transient receptor potential (TRP) cation channels, antagonism of calcium channels (and subsequently, synaptic transmission) and increasing membrane surface charge which in turn decreases excitability.

To date, several studies have explored the use of $\mathrm{Mg}$ in ameliorating CNS pathology, however, clinical trials have failed to deliver on the promise of the effectiveness of $\mathrm{Mg}$ in animal

From the Division of Fundamental Neurobiology (PAA, PLC), Toronto Western Research Institute; Division of Neurology (NP, PLC), Toronto Western Hospital; Departments of Medicine (Neurology) and Physiology (PLC), University of Toronto, Toronto, Ontario, Canada.

Received August 23, 2011. Final Revisions Submitted December 1, 2011. Correspondence to: Peter L. Carlen, Toronto Western Hospital, 5W-442, 399 Bathurst St., Toronto, Ontario, M5T2S8, Canada. 
studies [see ${ }^{5}$ for review]. For example, in a large clinical trial, $\mathrm{Mg}$ failed to show any benefit in decreasing the morbidity and mortality associated with stroke ${ }^{6}$. Nevertheless, when administered along with adrenocorticotropic hormone (ACTH), MgSO4 demonstrated a significant decrease in seizures in children with infantile spasms ${ }^{7}$. However, no clinical trials have investigated the efficacy of $\mathrm{Mg}$ in the treatment of recurrent epileptic seizures in adults. We report a small case series illustrating the benefit of oral $\mathrm{Mg}$ supplementation in drug intractable epileptic seizures.

\section{Methods}

Charts were reviewed retrospectively, using both electronic and paper medical records, from an outpatient epilepsy clinic at the Toronto Western Hospital; a tertiary center for epileptic patients who are often refractory to conventional pharmacotherapy. All charts depicting the initiation of empiric trials of Mg from August 2005 to January 2011, with at least one follow-up occurring after three months of $\mathrm{Mg}$ therapy, were included. Seizure frequency was recorded from patient histories, and reported as seizure days/month, and not the total number of seizures. Several patients reported having several seizures on a daily basis, which are reported here as 30 seizure days/month, the maximum possible. The pre-Mg seizure frequency was taken from the clinic note written on the day of $\mathrm{Mg}$ initiation. $\mathrm{Mg}$ was usually initiated as $\mathrm{MgO} 420 \mathrm{mg}$ twice a day, daily, and in some patients, was increased to three times a day, daily. Subsequent follow up notes were used to gauge patient compliance as well as $\mathrm{Mg}$ therapeutic and adverse effects. Seizure frequency was pooled into the following groups: 1) Pre-Mg 2) Follow-up at 36 months 3) Follow-up at 6-12 Months and 4) Follow-up at 1218 months.

Statistical analysis consisted of a one-way repeated measures ANOVA with post-hoc analysis using the Holm-Sidak method, and included tests for normality of data, conducted using SigmaPlot version 11 (Systat Software Inc., San Jose, CA, USA), with a minimum level of significance at $\mathrm{p}<0.05$. Sub group analysis was conducted using a two-way repeated measures ANOVA.

\section{RESUlts}

All results are reported in the Table. Both the electronic medical record and paper chart were reviewed for an initial cohort of twenty-seven patients. One patient record was in duplicate, one patient agreed but never took $\mathrm{Mg}$, while three took $\mathrm{Mg}$ inconsistently, and thus were not included in the analysis. Twenty-two patients were included in the analysis, 55\% female, with an age of $37.1 \pm 10.4$ years (average \pm SD) at $\mathrm{Mg}$ initiation and initial seizure occurring at an age of $15.5 \pm 10.0$ years (excluding neonatal and febrile seizures). Anti-epileptic drug regimen included $2.8 \pm 0.9$ drugs and $45 \%$ of patients had some sort of neurological surgery, either as a cause or treatment of their seizure disorder.

Average seizure frequency for the group was $15.3 \pm 13.2$ seizure days/month. At first follow-up (3-6 months), seizure frequency was $10.2 \pm 12.6$ seizure days/month $(\mathrm{p}=0.021)$. At second follow up (6-12 months), consisting of $15 / 22$ patients, seizure frequency was $7.8 \pm 10.0(\mathrm{p}=0.004)$. Only $2 / 22$ patients had a third follow up, with a seizure frequency of 2.5 . The only adverse drug event reported was diarrhea, reported by four patients, three of which were on the $\mathrm{MgO}$ three times a day regimen. Two of these patients were switched to Mg-lactate, and subsequently reported increased gastrointestinal tolerability.

Twenty-seven percent $(6 / 22)$ had a primary seizure disorder (generalized tonic clonic [GTC] or drop attacks) with the remaining 73\% (16/22) having partial seizures (complex-partial seizures [CPS] - many of whom had secondary generalization, or simple partial). While $\mathrm{Mg}$ seemed more effective at increasing seizure free days/month (i.e. decreasing seizures) amongst the primary epilepsies, sub-group analysis via two-way repeated measures ANOVA comparing the effectiveness of $\mathrm{Mg}$ supplementation on primary generalized versus partial seizures revealed no statistical difference $(p>0.05)$.

Responder rates at first follow-up were as follows: $32 \%$ $(7 / 22)$ had a reduction of $75 \%$ or greater in the number of seizure days per month, while $41 \%(9 / 22)$ had a reduction of $50 \%$ or greater in the number of seizure days per month. At second follow-up, both the $75 \%$ and $50 \%$ responder rates were $5 / 14$ (36\%), suggesting that the efficacy of $\mathrm{MgO}$ on seizures may be bimodal i.e. there may be a group of responders and nonresponders. Of those who qualified as responders, 3/5 were classified as GTC, one with CPS and one with CPS with secondary generalization. Examination of the anti-seizure drugs did not reveal any obvious trends. This group of five patients were on an average of $2.8 \pm 0.8$ anti-epileptic medications, the most common being lamotrigine phenytoin, topiramate and valproate, all shared by two patients in the group. Four of the five were on a regimen of $\mathrm{MgO}$ twice a day dosing, compared to $68 \%$ of the cohort (15/22) who were on a regimen of $\mathrm{MgO}$ twice or more per day. Two of the 22 patients $(9 \%)$ achieved seizure freedom

Serum Mg levels were not drawn as a part of monitoring oral $\mathrm{Mg}$ therapy, however, several patients had serum Mg levels drawn as a part of routine in-patient hospitalizations. Eight patients had pre-treatment serum $\mathrm{Mg}$ levels drawn and four patients had post-Mg treatment levels drawn. All levels were within the normal range.

\section{Discussion}

Magnesium has been widely used by the obstetrics community for years in the treatment of eclampsia. Other clinical applications of $\mathrm{Mg}$ supplementation include ICU protocols, torsades ventricular arrhythmias, parathyroid syndromes, end-stage renal disease, insulin resistance and cardiovascular disease ${ }^{8}$. While toxicity may manifest with respiratory depression and death, most common adverse events are diarrhea and hyporeflexia. Clinical signs of $\mathrm{Mg}$ imbalance often do not correlate with serum levels, as less than $1 \%$ is found in serum, with the bulk found in bone or intracellularly, where it acts as an important biochemical mediator ${ }^{9}$. When serum levels were measured in the present study, $\mathrm{Mg}$ levels were all normal both before and after Mg supplementation. Reports have shown that seizure patients have lower ionized $\mathrm{Mg}^{2+}$, and higher ionized $\mathrm{Ca}^{2+} / \mathrm{Mg}^{2+}$ ratios ${ }^{10}$, however, $\mathrm{Mg}$ levels do not correlate with seizure probability in the treatment of eclampsia ${ }^{11}$.

Notwithstanding its wide spread clinical use and relatively benign adverse effects, $\mathrm{Mg}$ has not been tried for the treatment of patients established epileptic seizures, with the exception of its reported efficacy against infantile spasm as adjunctive 
Table: The efficacy of oral Mg supplementation in patients with medically intractable epilepsy

\begin{tabular}{|c|c|c|c|c|c|c|c|c|c|c|c|c|c|}
\hline & \multirow[b]{2}{*}{ Sex } & \multirow[b]{2}{*}{ Age } & \multirow[b]{2}{*}{ Seizure Type } & \multirow[b]{2}{*}{ Age @ 1st Sz } & \multirow[b]{2}{*}{ NeuroSx } & \multirow[b]{2}{*}{ MgDose } & \multirow[b]{2}{*}{ AEDs } & \multicolumn{3}{|c|}{ Seizure Frequency } & \multirow[b]{2}{*}{$3 r d f / u$} & \multirow{2}{*}{$\begin{array}{l}\% \text { Change } \\
\text { after } 1 \text { st f/u }\end{array}$} & \multirow{2}{*}{$\begin{array}{l}\% \text { Change } \\
\text { after } 2 \text { nd f/u }\end{array}$} \\
\hline & & & & & & & & Initial & $1 \mathrm{st} \mathrm{f} / \mathrm{u}$ & 2nd f/u & & & \\
\hline 1 & $M$ & 43 & SP & & No & 420 QHS & $\mathrm{B}, \mathrm{C}, \mathrm{H}$ & 3 & 1 & & & -67 & \\
\hline $2^{*}$ & $\mathrm{~F}$ & 36 & CPS & & No & 420 BID & $A, E, H$ & 30 & 5 & 6 & & -83 & -80 \\
\hline 3 & $\mathrm{~F}$ & 21 & CPS & \#\#6 & Yes & 420 BID - QID & $C, G, I, J$ & 30 & 30 & 18 & & 0 & -40 \\
\hline 4 & M & 56 & CPS & 36 & Yes & 420 BID & $\mathrm{B}, \mathrm{C}, \mathrm{H}$ & 30 & 30 & 30 & & 0 & 0 \\
\hline 5 & M & 31 & CPS & & Yes & 420 QHS & $\mathrm{B}, \mathrm{C}, \mathrm{F}, \mathrm{O}$ & 8 & 8 & 8 & & 0 & 0 \\
\hline 6 & $\mathrm{~F}$ & 51 & CPS & & No & 420 BID & $\mathrm{K}$ & 7 & 0.5 & 0 & & -93 & \\
\hline $7^{*}$ & $M$ & 31 & CPS & 28 & Yes & 420 BID - QID & $B, C$ & 7 & 6 & 4 & 3 & -14 & -43 \\
\hline 8 & $\mathrm{~F}$ & 31 & CPS & & No & 420 QHS & $\mathrm{B}, \mathrm{C}, \mathrm{H}$ & 4 & 1 & 4 & & -75 & 0 \\
\hline 9 & $M$ & 21 & $\mathrm{CPS} 2^{\circ} \mathrm{GTC}$ & \# 12.5 & No & 420 BID & $\mathrm{F}, \mathrm{H}, \mathrm{I}$ & 30 & 0 & & & -100 & \\
\hline $10^{*}$ & $\mathrm{~F}$ & 29 & CPS $2^{\circ} \mathrm{GTC}$ & 4 & Yes & $420 \mathrm{BID}-\mathrm{QHS}$ & $\mathrm{B}, \mathrm{N}$ & 30 & 2 & 2 & 2 & -93 & -93 \\
\hline 11 & $\mathrm{~F}$ & 42 & $\mathrm{CPS} 2^{\circ} \mathrm{GTC}$ & 12 & Yes & 420 BID & $\mathrm{I}, \mathrm{K}, \mathrm{N}$ & 30 & 30 & 30 & & 0 & 0 \\
\hline 12 & M & 27 & $\mathrm{CPS} 2^{\circ} \mathrm{GTC}$ & 4 & Yes & 420 BID & $L, N, P$ & 30 & 30 & & & 0 & \\
\hline $13^{*}$ & $\mathrm{~F}$ & 24 & CPS $2^{\circ} \mathrm{GTC}$ & 13 & No & 420 QHS & $\mathrm{B}$ & 30 & 30 & & & 0 & \\
\hline $14^{*}$ & $\mathrm{~F}$ & 36 & CPS $2^{\circ} \mathrm{GTC}$ & & No & 420 QHS - BID & $B, C$ & 3.5 & 3 & 2 & & -14 & -43 \\
\hline $15^{\star}$ & $\mathrm{F}$ & 28 & $\mathrm{CPS} 2^{\circ} \mathrm{GTC}$ & 11 & No & 420 BID - TID & $\mathrm{C}, \mathrm{H}, \mathrm{L}$ & 3.5 & 4 & & & 14 & \\
\hline $16^{*}$ & $\mathrm{~F}$ & 51 & $\mathrm{CPS} 2^{\circ} \mathrm{GTC}$ & 10 & No & 420 BID & $\mathrm{B}, \mathrm{H}, \mathrm{I}$ & 1 & 1 & & & 0 & \\
\hline $17^{*}$ & M & 44 & Drop attacks & 11 & yes & 420 BID & $B, H, M$ & 5 & 1 & & & -80 & \\
\hline $18^{*}$ & $\mathrm{~F}$ & 48 & GTC & 8 & Yes & 420 BID & $\mathrm{L}, \mathrm{O}$ & 30 & 30 & 3 & & 0 & -90 \\
\hline 19 & $M$ & 31 & GTC & & No & 420 BID & $C, H, M, C$ & 30 & 4 & 3 & & -87 & -90 \\
\hline 20 & $\mathrm{~F}$ & 46 & GTC & & No & 420 QHS & $\mathrm{D}, \mathrm{L}, \mathrm{N}$ & 5 & 1.3 & 0.3 & & -74 & -94 \\
\hline 21 & $M$ & 48 & GTC & 20 & No & 420 QHS & $\mathrm{B}, \mathrm{H}, \mathrm{L}$ & 2 & 3 & 3 & & 50 & 50 \\
\hline 22 & M & 42 & GTC & 25 & Yes & 420 BID & $\mathrm{H}, \mathrm{L}$ & 2 & 3 & 3 & & 50 & 50 \\
\hline
\end{tabular}

\# History of febrile seizures in the past; \#\# History of neonatal seizures in the past; * See patient note below; Seizure frequencies are reported as seizure days per month. Those with several seizures/day are reported simply as 30 . Initial, 1st, 2nd, 3rd indicate follow-up visits as detailed in the text. *Patient Notes: 2 - Lamotrigine discontinued secondary to rash at first follow-up. Leviteracitam 500mg twice a day started. 7 - Lamotrigine started and subsequently discontinued during $\mathrm{MgO}$ trial. Valproate increased to $1000 \mathrm{mg}$ twice a day from $750 \mathrm{mg}$. 10 - MgO dose decreased secondary to diarrhea. 13 - Patient started on prazosin for PTSD. 14 - Patient began having diarrhea with increased dosing and was subsequently decreased. 15 Started on lorazepam for panic attacks. 16 - Patient started on Mg-Lactate secondary to diarrhea and GI intolerability at first follow-up. 17 Vigabatrin initiated, then discontinued abruptly due to suspicion of visual field changes; Patient also began course of acupuncture during $\mathrm{MgO}$ trial. 18 - Patient was placed on Mg-Lactate secondary to diarrhea and GI intolerability at second follow-up. Abbreviations: f/u - follow-up; CPS Complex partial seizures; $2^{\circ}$ - secondary, GTC - generalized tonic-clonic seizures, SP - simple partial seizures, Sz - seizures, NeuroSx - neurosurgery; EtOH - alcohol abuse and withdrawal; FAS - fetal alcohol syndrome; TBI - traumatic brain injury, VNS - vagal nerve stimulator; SDH subdural hematoma; SE: status epilepticus; QHS: nightly; BID: twice a day; TID: three times a day; QID: four times a day. AEDs - anti-epileptic drugs: acetazolamide (A), carbamazepine (B), clobazam (C), clonazepam (D), diazepam (E), gabapentin (F), lacosamide (G), lamotrigine (H), levetiracetam $(\mathrm{I})$, oxcarbazepine $(\mathrm{J})$, phenobarbital $(\mathrm{K})$, phenytoin $(\mathrm{L})$, primidone $(\mathrm{M})$, topiramate $(\mathrm{N})$, valproate $(\mathrm{O})$, vigabatrin $(\mathrm{P})$.

therapy with $\mathrm{ACTH}^{7}$. It is widely accepted that a low $\mathrm{Mg}$ perfusion of in vitro brain preparations will readily generate seizures $^{12}$. However, animal research on the anti-seizure efficacy of $\mathrm{Mg}$ is equivocal. No effect of $\mathrm{Mg}$ was reported against maximal electroconvulsive shock (MES) and pentylenetetrazol $(\mathrm{PTZ})^{13}$, or kainate ${ }^{14}$ models of seizures in vivo. Conversely, other experiments have demonstrated that peripherally administered $\mathrm{Mg}$ accumulates in the brain and increases amygdala kindling threshold in the rat $^{15}$. It also decreases seizures associated with intracranial NMDA injection when administered both centrally and peripherally ${ }^{16}$ and was shown to augment sub-therapeutic VPA in the PTZ model of rat ${ }^{17}$. Mg also decreased epileptiform discharges from cortical foci generated by penicillin $^{18}$, however, did not suppress epileptiform EEG discharges in eclamptic patients ${ }^{19}$, which is a similar finding in penicillin-induced seizure foci in anesthetized cats ${ }^{20}$.
A randomized clinical trial investigating the neuroprotective effects of continuous $\mathrm{Mg}$ infusion in patients with traumatic brain injury did not demonstrate any positive benefits ${ }^{21}$, yet $\mathrm{Mg}$ has been successful in the treatment of convulsions associated with porphyria ${ }^{22}$. Intravenous $\mathrm{Mg}$ has been used in the past to successfully treat status epilepticus associated with Alper's Syndrome, a triad of developmental delay, intractable seizures and hepatic failure ${ }^{23}$.

Our patient population represents seizure patients who are the most difficult to treat medically. Nevertheless, $\mathrm{Mg}$ supplementation was able to significantly decrease the amount of seizure days/month, with two patients reportedly becoming seizure-free. However, there are multiple shortcomings which limit the ability to extrapolate these data. Firstly, this study was an open label, uncontrolled empiric study of the efficacy of $\mathrm{Mg}$ in a small population of patients with drug resistant seizures, 
heterogeneous medical histories and assorted anti-seizure drug regimens.

Secondly, $\mathrm{MgO}$, one of the most affordable preparations, was used by most patients. However, its limited bioavailability, welldocumented in the literature ${ }^{24}$, is similar to other commonly used $\mathrm{Mg}$ compounds ${ }^{25}$. Magnesium supplementation by mouth may be absorbed throughout the entire length of the small intestine, however, the bulk is associated with uptake in the distal jejunum and ileum, mainly by a passive intercellular process ${ }^{25}$. Increased bioavailability of organic $\mathrm{Mg}$ compounds, such as $\mathrm{Mg}$-Acetate, Mg-Lactate and Mg-Gluconate have been documented using both radio-isotopes and urinary $\mathrm{Mg}$ concentrations ${ }^{25}$, and would be a better preparation for oral $\mathrm{Mg}$ delivery in future studies.

Similarly, the ability of $\mathrm{Mg}$ to penetrate the blood brain barrier in therapeutically relevant concentrations has been the subject of some debate [see REF ${ }^{5}$ for review]. Using $\mathrm{Mg}^{28} \mathrm{Cl}$, Oppelt et al, $(1963)^{26}$ concluded that $\mathrm{Mg}$ uptake into the CSF from the blood was an active process, keeping CSF concentrations greater than serum concentrations, and this was not affected by increasing Mg concentrations 3-4 fold. Similarly, Sun and colleagues (2009) $)^{27}$ found no increase in CSF Mg when $\mathrm{MgSO}_{4}$ was injected intraperitoneally, in mice.

And yet, several groups have noted increased CSF Mg when supplemented parenterally, including pre-eclamptic paients ${ }^{28}$ and neurosurgical patients undergoing venticulostomy drainage ${ }^{29}$ or craniectomy $^{30}$. Similarly, rats injected intraperitoneally with $\mathrm{MgSO}_{4}$ had significantly elevated CSF Mg levels at four hours, which coincided with elevated hippocampal seizure thresholds ${ }^{31}$.

In all studies, including those where CSF $\mathrm{Mg}$ did not significantly increase, a significant rise in serum $\mathrm{Mg}$ was noted. However, when $\mathrm{Mg}$ levels were measured in this study as part of routine inpatient hospitalization, levels were all within normal limits. The usefulness of $\mathrm{Mg}$ levels prepared by the clinical laboratory is questionable, given that $99 \%$ of magnesium is intracellular [bone (53\%); soft tissues (46\%)] with $1 \%$ in the blood $^{26}$. Of the $1 \%$, only the free ionized form is capable of transport across the blood brain barrier.

Future studies should include a blinded, placebo controlled protocol, with appropriate long term follow up, using organic $\mathrm{Mg}$ preparations such as $\mathrm{Mg}$-Acetate, lactate or gluconate, and should coincide with monitoring of CSF $\mathrm{Mg}$ in attempt to correlate $\mathrm{Mg}$ levels with anti-seizure effectiveness. Monitoring intracellular red blood cell magnesium is another possible assay which may correlate with a decrease in seizures, and less invasive than obtaining CSF.

Standard anti-seizure medications are known for their wide adverse side-effect profile, whereas the adverse events associated with $\mathrm{Mg}$ supplementation, which is quite inexpensive, are relatively benign and easily monitored. Given these data, clinical trials of the efficacy of $\mathrm{Mg}$ supplementation to routine anti-seizure therapy in medically responsive epilepsy are warranted.

\section{REFERENCES}

1. Lazard EM. A preliminary report on the intravenous use of magnesium sulfate in puerperal eclampsia. Am J Obstet Gynecol. 1925;9:178-88.

2. Duley L, Henderson-Smart DJ, Walker GJ, Chou D. Magnesium sulphate versus diazepam for eclampsia. Cochrane Database Syst Rev. 2010;8(12):CD000127.
3. Duley L, Henderson-Smart DJ, Chou D. Magnesium sulphate versus phenytoin for eclampsia. Cochrane Database of Syst Rev. 2010;6(10):CD000128.

4. Goldman RS, Finkbeiner SM. Therapeutic use of magnesium sulfate in selected cases of cerebral ischemia and seizure. N Engl J Med. 1988;319(18):1224-5.

5. Sen A, Gulati A. Use of magnesium in traumatic brain injury. Neurotherapeutics. 2010;7(1):91-9.

6. Muir KW, Lees KR, Ford I, Davis S, Investigators. IMEiSIS. Magnesium for acute stroke (Intravenous Magnesium Efficacy in Stroke trial): randomised controlled trial. Lancet. 2004;363 (9407):439-45.

7. Zou L-P, Wang X, Dong C-H, Chen C-H, Zhao W, Zhao R-Y. Three-week combination treatment with ACTH + magnesium sulfate versus ACTH monotherapy for infantile spasms: A 24week, randomized, open-label, follow-up study in China. Clin Ther. 2010;32(4):692-700.

8. Kanbay M, Goldsmith D, Uyar ME, Turgut F, Covic A. Magnesium in Chronic Kidney Disease: Challenges and Opportunities. Blood Purif. 2010;29(3):280-92.

9. Elin RJ. Magnesium metabolism in health and disease. Dis Mon. 1988;34(4):161-218.

10. Sinert R, Zehtabchi S, Desai S, Peacock P, Altura BT, Altura BM. Serum ionized magnesium and calcium levels in adult patients with seizures. Scand J Clin Lab Invest. 2007;67(3):317-26.

11. Aali BS, Khazaeli P, Ghasemi F. Ionized and total magnesium concentration in patients with severe preeclampsia-eclampsia undergoing magnesium sulfate therapy. J Obstet Gynaecol Res. 2007;33(2):138-43.

12. Mody I, Lambert JD, Heinemann U. Low extracellular magnesium induces epileptiform activity and spreading depression in rat hippocampal slices. J Neurophysiol. 1987 Mar;57(3):869-88.

13. Krauss GL, Kaplan P, Fisher RS. Parenteral magnesium sulfate fails to control electroshock and pentylenetetrazol seizures in mice. Epilepsy Res. 1989;4(3):201-6.

14. Mikati MA, Injibar H, Kurdi RM, et al. Effects of magnesium sulfate in kainic acid-induced status epilepticus. J Med Liban. 2006;54(4):200-4.

15. Standley CA, Irtenkauf SM, Cotton DB. Anticonvulsant Effects of Magnesium Sulfate in Hippocampal-Kindled Rats. J Biomed Sci. 1995;2(1):57-62.

16. Cotton DB, Hallak M, Janusz C, Irtenkauf SM, Berman RF. Central anticonvulsant effects of magnesium sulfate on N-methyl-Daspartate-induced seizures. Am J Obstet Gynecol. 1993;168(3 Pt 1):974-8.

17. Safar MM, Abdallah DM, Arafa NM, Abdel-Aziz MT. Magnesium supplementation enhances the anticonvulsant potential of valproate in pentylenetetrazol-treated rats. Brain Res. 2010; 1334:58-64.

18. Borges LF, Gücer G. Effect of magnesium on epileptic foci. Epilepsia. 1978;19(1):81-91.

19. Sibai BM, Spinnato JA, Watson DL, Lewis JA, Anderson GD. Effect of magnesium sulfate on electroencephalographic findings in preeclampsia-eclampsia. Obstet Gynecol. 1984;64 (2):261-6.

20. Koontz WL, Reid KH. Effect of parenteral magnesium sulfate on penicillin-induced seizure foci in anesthetized cats. Am J Obstet Gynecol. 1985;153(1):96-9.

21. Temkin NR, Anderson GD, Winn HR, et al. Magnesium sulfate for neuroprotection after traumatic brain injury: a randomised controlled trial. Lancet Neurol. 2007;6(1):29-38.

22. Sadeh M, Blatt I, Martonovits G, Karni A, Goldhammer Y. Treatment of porphyric convulsions with magnesium sulfate. Epilepsia. 1991;32(5):712-5.

23. Visser N, Braun K, Leijten F, van Nieuwenhuizen O, Wokke J, van den Bergh W. Magnesium treatment for patients with refractory status epilepticus due to POLG1-mutations. J Neurol. 2011;258 (2):218-22.

24. Firoz M, Graber M. Bioavailability of US commercial magnesium preparations. Magnes Res. 2001;14(4):257-62.

25. Coudray C, Rambeau M, Feillet-Coudray C, et al. Study of magnesium bioavailability from ten organic and inorganic $\mathrm{Mg}$ 
salts in Mg-depleted rats using a stable isotope approach. Magnes Res. 2005;18(4):215-23.

26. Oppelt WW, MacIntyre I, Rall DP. Magnesium exchange between blood and cerebrospinal fluid. Am J Physiol. 1963;205(5): 959-62.

27. Sun L, Kosugi Y, Kawakami E, Piao YS, Hashimoto T, Oyanagi K. Magnesium concentration in the cerebrospinal fluid of mice and its response to changes in serum magnesium concentration. Magnes Res. 2009;22(4):266-72.

28. Thurnau GR, Kemp DB, Jarvis A. Cerebrospinal fluid levels of magnesium in patients with preeclampsia after treatment with intravenous magnesium sulfate: a preliminary report. Am J Obstet Gynecol. 1987;157(6):1435-8.
29. McKee J, Brewer R, Macy G, Borel C, Reynolds J, Warner D. Magnesium neuroprotection is limited in humans with acute brain injury. Neurocrit Care. 2005;2(3):342-51.

30. Fuchs-Buder T, Tramèr MR, Tassonyi E. Cerebrospinal Fluid Passage of Intravenous Magnesium Sulfate in Neurosurgical Patients. J Neurosurg Anesthesiol. 1997;9(4):324-8.

31. Hallak M, Berman RF, Irtenkauf SM, Evans MI, Cotton DB. Peripheral magnesium sulfate enters the brain and increases the threshold for hippocampal seizures in rats. Am J Obstet Gynecol. 1992;167(6):1605-10. 